\title{
Extracellular Enzymes and Antimicrobial Activities of Celluloytic Bacteria from the Gut of Black Surgeonfish (Acanthurus gahhm)
}

\author{
Francis S. Legario ${ }^{1}$ and Agile J. Pesina ${ }^{2}$ \\ ${ }^{1}$ Natural Sciences Department/Research Services Division \\ Iloilo Science and Technology University, ${ }^{2}$ Science Department, St. Paul University \\ Iloilo
}

\section{ABSTRACT}

The diverse microflora of the gastrointestinal tracts of fish is a promising frontier for the discovery of beneficial bacteria and further microbiological investigations. Isolation, characterization, and determination of the enzymatic and antibacterial activities of the culturable cellulolytic bacteria from the gut of Acanthurus gahhm (black surgeonfish) were investigated. The bacterial strains were isolated from the three gut regions (anterior, mid and hind) using minimum medium. The isolates were characterized morphologically, biochemically and physiologically using standard methods. The isolates were qualitatively tested for activities of extracellular enzymes such as in amylase, protease and lipase. Results showed that the cellulolytic bacteria were Grampositive bacilli, coccobacilli and cocci exhibiting varied biochemical activities most notably fermentative abilities. Physiological tests revealed that the bacteria were able to tolerate high salt concentration. The strains exhibited varying levels of activities for protease and lipase but not on amylase. The isolates were further tested for their antibacterial activity and only one isolate, AG $5 \mathrm{H}$ showed signs of efficacy through a zone of inhibition against $S$. aureus but not for E. coli. The isolate AG5H is interesting because of its high level of enzymatic activities and antibacterial action, which can be exploited for further study for fish health and nutrition and other industrial applications.

Keywords: cellulolytic; gut; surgeonfish; enzymes; antibacterial

\section{INTRODUCTION}

Gastrointestinal (GI) tract of vertebrates becomes colonized with bacteria shortly after birth or hatching. These include transient microorganisms and autochthonous bacteria, which develop into relatively stable populations that are characteristic of the species (Edwards 1998).

Correspondence: Francis S. Legario Address: Natural Sciences Department/Research Services Division Iloilo Science and Technology University, 6521-A E-mail: f.legario@yahoo.com.ph DOI: 10.32945/atr3913.2017 
Gastrointestinal microflora in the foregut, midgut and hindgut are varied and depend upon the environment. The bacterial flora of the gastrointestinal tract represent a very important and diversified enzymatic potential because the enzymatic mass lodged in the digestive tract might interfere in a considerable way with a major part on the metabolism in host animal (Bairagi et al 2002).

Digestive and extracellular enzymes with associated microbes in the tract of alimentary canal play an important role in the digestion of food. It may be intermittently or permanently populated with microorganisms from the environment that could be beneficial or pathogenic in influence. The bacterial flora within the GI tract of fish shows very broad and variable enzymatic potential, and these enzymatic processes may interfere positively on fish (Ray et al 2010). Research conducted in carps showed the beneficial aspects of gut-associated microbiota in the host fish with regard to nutrition (Ghosh et al 2002). Meanwhile, information on the enzymeproducing bacteria in tropical herbivorous species specifically on surgeonfish is scanty if not absent.

Black surgeonfish, Acanthurus gahhm, is an herbivorous fish that has a great potential for aquaculture because of its fatty white flesh. Moreover, due to the effect of climate change, herbivorous species are candidate aquaculture species to mitigate algal blooms in our ocean waters due to their ability to sequester carbon (Randall 1961 a \& b, FAO 2008). The present study was undertaken because of the potential commercial importance of black surgeonfish. The aim of this study was to identify the morphogical and biochemical components of cellulolytic bacteria and to analyse the enzyme producing bacteria with special reference to amylase, protease and lipase in the gastrointestinal tract. It was also a goal to test whether these cellulolytic bacteria have antibacterial activities against human pathogens.

\section{MATERIALS AND METHOD}

\section{Fish Samples}

Surgeonfishes were sampled from Igang Marine Station of SEAFDEC Aquaculture Department located southwest of Guimaras Island. Average body weight was $136 \mathrm{~g}$ while average body length was $22 \mathrm{~cm}$ (Fig. 1). The fish samples were starved $48 \mathrm{hr}$ to clear their gut and remove allochthonous (transitory) bacteria. The fishes were dissected aseptically and their alimentary tracts removed. The GI tracts were then divided into three portions namely anterior gut, midgut and hindgut. The samples were cut into pieces and flushed carefully with $0.9 \%$ sterile NSS Normal saline solution) using an injection syringe $(1 \mathrm{~mL})$ in order to remove nonadherent (allochthonous) microflora. 


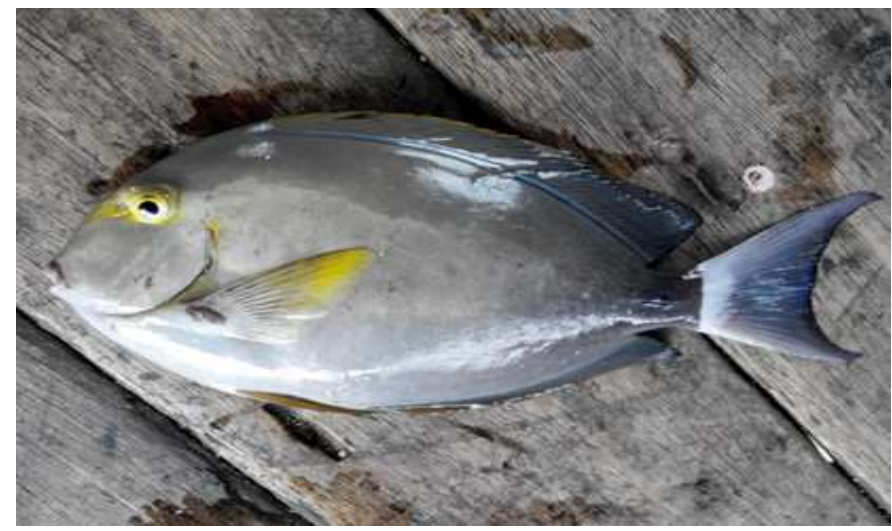

Figure 1. Mature surgeonfish (Acanthurus gahhm)

\section{Bacterial Isolation}

Tissue sections from the gastrointestinal tract (anterior gut, midgut and hindgut) were separately placed in a Basal Salt Media containing Whatman filter paper for the isolation of cellulolytic bacteria. There were three replicates for each gut segment. Inoculated broth was incubated at room temperature $\left(20-25^{\circ} \mathrm{C}\right)$ for seven days. Bacterial colonies capable of utilizing cellulose as sole source of carbon were streaked on a Cellulose Agar medium and incubated at room temperature $\left(20-25^{\circ} \mathrm{C}\right)$ for 48 hours.

The cellulose-degrading ability of bacterial isolates was confirmed through streaking the bacterial colonies on a Cellulose Congo-Red Medium.

After 48 hours, the plates were examined. Different types of colonies in each plate were isolated, streaked and purified.

\section{Morphological Characterization}

Among the different types of colonies, streaked and purified, only five isolated cultures were selected for further study based on their relative abundance. The selected isolates were observed for colony characteristics. These colony characteristics included color, shape, margin, elevation and texture.

Isolates were Gram-stained using the method of Hucker. Stained smears were viewed under a light microscope and were classified as Grampositive or Gram-negative. Cell shape was also determined whether cocci, bacilli or spiralli.

Spore staining was also done to determine if the bacterial isolates produced endospores and can withstand harsh conditions.

\section{Biochemical Characterization}

Isolates underwent biochemical testing at Diagnostic Service, Fish Health section, SEAFDEC/AQD Tigabauan, Iloilo. Bacterial isolates were 
subjected to an oxidase test, catalase test and conventional biochemical tests namely oxidative/fermentative (OF) open tube, OF close tube, gas production from glucose, nitrate reduction, gelatin liquefaction, decarboxylation of amino acids (lysine, arginine, and ornithine), indole, hydrogen sulfide production, citrate utilization, methyl red, VP (VoguesProskauer), acid production (arabinose, glucose, mannitol, sucrose, inositol) and carbon source (arabinose, glucose and glucosamine).

\section{Physiological Characterization}

Growth characteristics of the isolates were studied as affected by different factors. Bacterial isolates tested for their growth on different temperatures $\left(4,20,35\right.$ and $\left.40^{\circ} \mathrm{C}\right)$ and different $\mathrm{NaCl}$ concentration $(0,3,6$ 8 and $10 \%)$.

\section{Qualitative Assays for Exoenzyme Production}

Five isolates were primarily selected (on the basis of growth potential at $30^{\circ} \mathrm{C}$ ) for qualitative enzyme assay.

Extracellular amylase production was determined through inoculation of isolates on SA plates followed by incubation at $30^{\circ} \mathrm{C}$ for 24 hours. The culture plates were flooded with Grams Iodine solution. Identification of amylase activity is through the formation of a transparent zone (halo) surrounding the colony (Jacob \& Gerstein 1960).

Similarly, for extracellular protease, the isolates inoculated on PG plates were incubated at $30^{\circ} \mathrm{C}$ for 24 hours. The culture plates were flooded with $15 \% \mathrm{HgCl} 2$ and the appearance of a halo indicated the presence of proteolytic activity (Jacob \& Gerstein 1960).

For the determination of cellulase production, isolates grown on CMC plates at $30^{\circ} \mathrm{C}$ for 24 hours were flooded with $1 \%$ Congo Red dye. The appearance of a halo due to the hydrolyzed CMC surrounding the bacterial colony indicated cellulase production.

For lipase production, the appearance of a halo surrounding the colony in $1 \%$ tributyrin plates show the presence of lipase activity (Sangiliyandi \& Gunasekaran 1996).

There were three replicates for each experimental set. Qualitative extracelluar enzyme activity was assessed based on the measurement of the halo zone (diameter in $\mathrm{mm}$ ) around the colony and presented as scores, as follows: 0 (0-5mm), 1 (low, 6-10mm), 2 (moderate, 11-15mm), 3 (good, $16-20 \mathrm{~mm}$ ), 4 (high, $21-25 \mathrm{~mm}$ ), and 5 (very high, $>25 \mathrm{~mm}$ ) (Das 2014).

\section{Antibacterial Activity Assay (Spot on the Lawn)}

Isolates were inoculated in Nutrient broth (Merck) and incubated at $30^{\circ} \mathrm{C}$ for 30 minutes. Staphylococcus aureus and Escherichia coli were streaked on MHA (Mueller-Hinton Agar). Isolates from broth culture were 
pipetted ( $5 \mu \mathrm{l})$ on the central portion of the $S$. aureus and E. coli plates. The culture plates were incubated at $30^{\circ} \mathrm{C}$ for 24 hours.

For the positive control, Ciprofloxacin, was used. There were three replicates for each experimental set. The resistance of the isolates with $S$. aureus and $E$. coli were determined through the presence of a zone of inhibition around the isolate.

\section{Storage of Bacterial Specimens and Disposal of Waste}

Bacterial isolates were stored in glycerol broth and were kept in $-80^{\circ} \mathrm{C}$ freezer. The waste bacterial specimens were autoclaved at $200^{\circ} \mathrm{C}$ for 15 minutes for its proper disposal. Working areas were left neatly and disinfected with chlorine disinfectant.

\section{RESULTS AND DISCUSSION}

The sampled gut of black surgeonfish yielded bacterial isolates that showed similarity in morphological characteristics with regard to their colony, including the cell morphology (Tables 1 \& 2). The cellulose degrading bacteria were isolated from the entire region of the gut from the anterior (AG 1A) to the mid (AG 2M, AG3M, AG4M) to the hind gut (AG 5H). Four out of five isolates have circular colonies, only isolate $A G 5 \mathrm{H}$ had a rhizoid shape with a filamentous margin (Fig. 2). Gram staining revealed that all were Gram-positive with no luminescence. Morphologically three are coccobacilli, one cigar-shaped bacilli and one cocci (Fig. 3), and all without endospores (Table 2). The high presence of Gram-positive bacteria in the gut of herbivorous fishes have been demonstrated in several fish species including Scatophagus argus, Terapon jarbua, Mystus gulio and Etroplus suratensis (Das et al 2014). Some of the gram-positive bacteria found are Brevibacillus parabrevis and Bacillus licheniformis.

Table 1. Colony characteristics of the different bacterial isolates

\begin{tabular}{llllll}
\hline \multicolumn{5}{c}{ Colony Characteristics } \\
\hline Characteristic & AG1A & AG2M & AG3M & AG4M & AG5H \\
\hline Size & Grcular & Grcular & Grcular & Grcular & Grcular \\
Margin & Entire & Entire & Entire & Entire & Filamentous \\
Color & Yellowish & Yellowish & Whitish & Whitish & Whitish \\
Elevation & Flat & Flat & Raised & Flat & Flat \\
Texture & Butyrous & Butyrous & Butyrous & Butyrous & Butyrous \\
\hline
\end{tabular}


Table 2. Cell morphology of isolates

\begin{tabular}{lccccc}
\hline \multicolumn{5}{c}{ Cell Morphology } \\
\hline Test & AG 1A & AG 2M & AG 3M & AG 4M & AG 5H \\
\hline Gram stain & + & + & + & + & + \\
Cell shape & CB & CB & C & CB & B \\
Luminescence & - & - & - & - & - \\
Motility & + & + & - & + & - \\
Endospore & - & - & - & - & - \\
\hline
\end{tabular}

Legend: $\mathrm{B}=$ bacillus; $\mathrm{C}=$ coccus; $\mathrm{CB}=$ coccobacillus

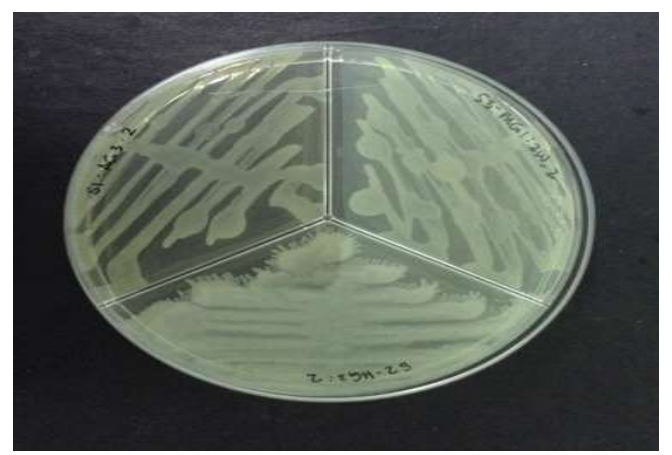

Figure 2. AG 5H colony growth (rhizoidal) in Nutrient Agar
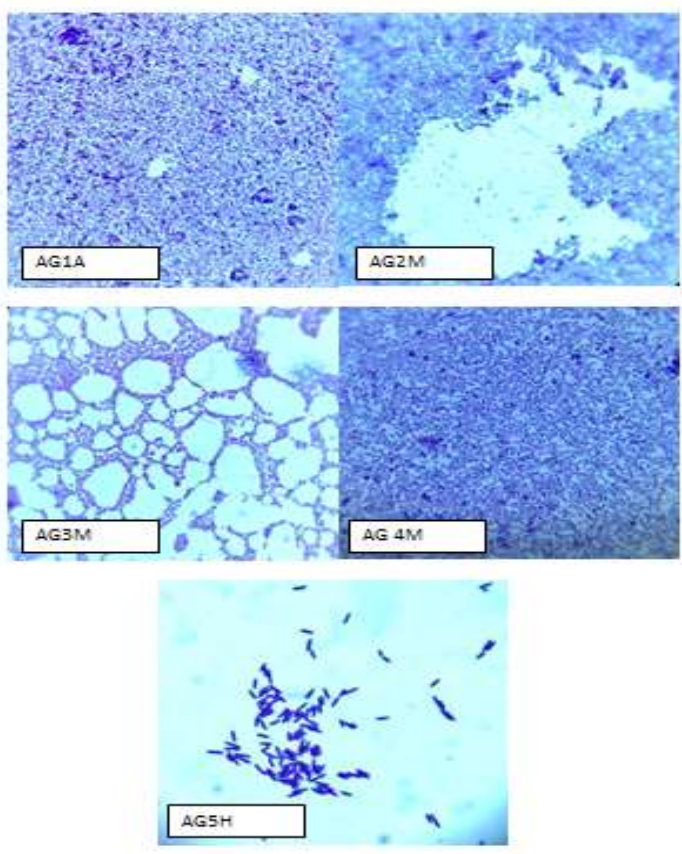

Figure 3. Gram stain of the 5 isolates showing different 
The bacterial strain AG A1 was catalase positive and oxidase negative. Conventional biochemical characterization (Table 3) showed that the isolate had no reaction in both oxidation and fermentation of glucose both in open and closed tube. Nitrate reduction was negative, gelatin liquefaction (indicating proteolytic activity) showed a positive result while decarboxylation of arginine was not applicable. The isolate was negative for hydrogen sulfide production, indole, methyl red and VP while it is able to utilize citrate as a carbon source. Acid production from different sugars namely arabinose, mannitol, sucrose, inositol and acid production from glucose were negative. Utilization of arabinose, glucose, and glucosamine as carbon source were negative.

Table 3. Biochemical characteristics of the isolates

\begin{tabular}{|c|c|c|c|c|c|}
\hline \multicolumn{6}{|c|}{ Biochemical Characteristics } \\
\hline Test & AG 1A & AG 2M & AG $3 M$ & AG $4 M$ & AG $5 \mathrm{H}$ \\
\hline Oxidase & + & - & - & + & + \\
\hline OF (open tube) & G & Y & Y & G & G \\
\hline OF (close tube) & G & Y & Y & G & G \\
\hline OF (interpretation) & NR & NR & 0 & NR & $\mathrm{F}$ \\
\hline Negative control & NR & + & NR & NR & NR \\
\hline Arginine & na & + & na & na & na \\
\hline Lysine & $\mathrm{Na}$ & - & na & na & na \\
\hline Ornithine & na & - & na & na & na \\
\hline \multicolumn{6}{|l|}{ Decarboxylase Test } \\
\hline Nitrate Reduction & - & - & - & - & + \\
\hline Gelatine Liquefaction & + & + & - & + & + \\
\hline SIM: Sulfide production & - & - & - & - & - \\
\hline SIM: Indole production & - & - & - & - & - \\
\hline Catalase & + & + & + & + & + \\
\hline Methyl Red (MR) & - & - & - & - & - \\
\hline VP & - & - & - & - & - \\
\hline $\begin{array}{l}\text { Triple Sugar Iron } \\
\text { (TSIA) }\end{array}$ & $\mathrm{R} / \mathrm{O}$ & $\mathrm{R} / \mathrm{O}$ & $\mathrm{R} / \mathrm{O}$ & $\mathrm{R} / \mathrm{O}$ & $\mathrm{R} / \mathrm{Y}$ \\
\hline \multicolumn{6}{|l|}{ Acid Fermentation } \\
\hline Arabinose & - & - & - & - & - \\
\hline Glucose & - & - & + & - & + \\
\hline Glucose (Gas prod.) & - & - & - & - & - \\
\hline Manaitol & - & - & - & - & + \\
\hline Sucrose & - & - & - & - & + \\
\hline Inositol & - & - & - & - & + \\
\hline \multicolumn{6}{|l|}{ Carbon source } \\
\hline Arabinose & - & - & - & - & + \\
\hline Glucose & - & - & + & - & + \\
\hline Glucosamine & - & - & - & - & + \\
\hline Citrate & + & + & + & + & + \\
\hline
\end{tabular}

Legend: $\mathrm{G}=$ green, $\mathrm{Y}=$ yellow, $\mathrm{NR}=$ no reaction, $\mathrm{O}=$ oxidative, $\mathrm{F}=$ fermentative, na = not assayed, $\mathrm{R} / \mathrm{O}=$ red/orange, $\mathrm{R} / \mathrm{Y}=\mathrm{red} /$ yellow 
The bacterial strain AG $2 \mathrm{M}$ was catalase positive and oxidase positive. Conventional biochemical characterization (Table 3) showed that the isolate had no reaction in both oxidation and fermentation of glucose both in open and closed tube. Nitrate reduction was negative, gelatin liquefaction (indicates proteolytic activity) showed a positive result while decarboxylation of arginine was positive. The isolate was negative for hydrogen sulfide production, indole, methyl red and VP while it was able to utilize citrate as a carbon source. Acid production from different sugars namely arabinose, mannitol, sucrose, inositol and acid production from glucose were negative. Utilization of arabinose, glucose, and glucosamine as carbon source were negative.

The bacterial strain AG 3M was catalase positive and oxidase negative. Conventional biochemical characterization (Table 3) showed that the isolate had a positive in oxidation and negative for fermentation of glucose. Nitrate reduction and gelatin liquefaction shows a negative result while decarboxylation of arginine was said to be not applicable. The isolate was negative for hydrogen sulfide production, indole, methyl red and VP while it was able to utilize citrate as a carbon source. Acid production from different sugars namely arabinose, mannitol, sucrose and inositol were negative while acid production from glucose was positive. Utilization of arabinose and glucosamine as carbon source were negative while glucose are positive.

The bacterial strain AG 4M was catalase positive and oxidase positive. Conventional biochemical characterization (Table 3) showed that the isolate had no reaction in both oxidation and fermentation of glucose both in open and closed tube. Nitrate reduction was negative, gelatin liquefaction (indicates proteolytic activity) shows a positive result while decarboxylation of arginine is said to be not applicable. The isolate was negative for hydrogen sulfide production, indole, methyl red and VP while it was able to utilize citrate as a carbon source. Acid production from different sugars namely arabinose, mannitol, sucrose, inositol and acid production from glucose were negative.

The bacterial strain AG 5H was catalase positive and oxidase positive. Conventional biochemical characterization (Table 3) showed that the isolate was negative in oxidation and positive in fermentation (F) of glucose both in open and closed tube. Nitrate reduction and gelatin liquefaction shows a positive result while decarboxylation of arginine was not applicable. The isolate was negative for hydrogen sulfide production, indole, methyl red and VP while it was able to utilize citrate as a carbon source. Acid production from different sugars namely arabinose was negative while mannitol, sucrose, inositol and acid production from glucose were positive. Utilization of arabinose, glucose, and glucosamine as carbon source were positive.

The presumptive identification of the isolates were based on Bergey's Manual of Systematics of Archaea and Bacteria (2015). Presumptively 
based on morphological and biochemical characteristics, isolates AG 1A, AG $2 \mathrm{M}$ and $4 \mathrm{M}$ belonged to the genus Carnobacterium (Gram -positive, non-endospore forming, motile rods). Carnobacteria are known to inhabit the gastrointestinal tract of marine fishes like the Atlantic salmon and wolf fish (Ringo 2008). For isolate AG 3M, it is presumtively identified as belonging to genus Micrococcus (Gram-positive cocci, catalase and oxidase postive). Studies have shown that Micrococci are an integral part of the microbiota of marine fishes like Rastrelliger kanagurta, Lates calcarifer, and Lutjanus fulviflamma (Ray et al 2012, Noornissabegum \& Revathi 2014). Lastly, isolate AG $5 \mathrm{H}$ was presumptively identified as belonging to the Genus Corynebacterium (Gram-positive rods, nonmotile rods). This bacterial genus is also found in the gut of fishes like the striped catfish $P$. hypohthalamus (Yaghobi et al 2014), striped bass M. saxatilis (Baya et al1992), Anabas testudineus (Banerjee et al 2016) common carp C. carpio (Rekhari et al 2014), and from goatfish Mulloidichthys samoensis (Colwell \& Liston 1962).

\section{Physiological Characteristics}

The isolates were tested for its tolerance against different incubation temperatures. Results show that the isolate grew best at $20-40^{\circ} \mathrm{C}$ but not at 10,20 , and $50^{\circ} \mathrm{C}$ (Table 4). This temperature requirement of the isolates is indicative of its habitat in the fish gut but which the temperature is approximately $20-30^{\circ} \mathrm{C}$.

Table 4. Physiological characteristics of the isolates for growth Temperature

\begin{tabular}{ccccccc}
\hline Growth at temperature & AG1A & AG2M & AG3M & AG4M & AG5H \\
\hline $4^{\circ} \mathrm{C}$ & - & - & - & - & - \\
$20^{\circ}$ & + & + & + & + & + \\
$35^{\circ} \mathrm{C}$ & + & + & + & + & + \\
$40^{\circ} \mathrm{C}$ & + & + & + & + & + \\
\hline
\end{tabular}

Legend: + = growth; - = no growth

The bacterial strain was also subjected to different salinity levels (Table 5). Bacterial isolate AG $1 \mathrm{~A}$ can tolerate salinity levels of $0-6 \%$ only while bacterial isolates $A G 2 M, A G 3 M$, and $A G 4 M$ could only tolerate salinity levels from $0-3 \%$. Bacterial isolate $A G 5 \mathrm{H}$ can tolerate salinity levels up to $0-8 \%$. The result showed that the isolates were all resident of the gut of the marine since the salinity level of seawater was approximately $3 \%$. 
Table 5. Physiological characteristics of the isolates for growth at different

\begin{tabular}{lcrrrr}
\hline $\mathrm{NaCl}$ concentration & AG $1 \mathrm{~A}$ & $\mathrm{AG} 2 \mathrm{M}$ & $\mathrm{AG} \mathrm{3M}$ & $\mathrm{AG} \mathrm{4M}$ & $\mathrm{AG} \mathrm{5H}$ \\
\hline $0 \%$ & + & + & + & + & + \\
$3 \%$ & + & + & + & + & + \\
$6 \%$ & + & - & - & - & + \\
$8 \%$ & - & - & - & - & + \\
$10 \%$ & - & - & - & - & - \\
\hline
\end{tabular}

Legend: + = growth; - = no growth

Screening of Isolates by Qualitative Assay for Exoenzyme Production

The activity of exoenzymes were determined based on the halo of clearing around the colony of the bacterial isolate. The diameter of the halo was measured in millimeters.

The bacterial isolate AG $1 \mathrm{~A}$ showed a positive result for proteolytic activity having an average of $14.3 \mathrm{~mm}=2$ (moderate, $11-15 \mathrm{~mm}$ ) (Table 6). Lipase activity was also present with an average of $9 \mathrm{~mm}=1$ (low, $6-10 \mathrm{~mm}$ ). Amylase activity showed a negative result.

Table 6. Extracellular enzyme activities of the isolates based on their halo formation

\begin{tabular}{lccccc}
\hline Enzyme & AG $1 \mathrm{~A}$ & AG $2 \mathrm{M}$ & AG 3M & AG 4M & AG 5H \\
\hline Protease & $14.3 \mathrm{~mm}$ & $13 \mathrm{~mm}$ & - & $14.6 \mathrm{~mm}$ & $23 \mathrm{~mm}$ \\
Amylase & - & - & - & - & - \\
Lipase & $9 \mathrm{~mm}$ & - & $14.5 \mathrm{~mm}$ & $7.3 \mathrm{~mm}$ & $30 \mathrm{~mm}$ \\
\hline
\end{tabular}

Legend: - = no halo formation

The bacterial isolate AG $2 \mathrm{M}$ showed a positive result for proteolytic activity having an average of $13 \mathrm{~mm}=2$ (moderate, $11-15 \mathrm{~mm}$ ). Amylase and lipase activity showed a negative result.

The bacterial isolate AG $3 \mathrm{M}$ showed a positive result for lipase activity was also present with an average of $14.5 \mathrm{~mm}=2$ (moderate, $11-15 \mathrm{~mm}$ ). Amylase, and proteolytic activity showed a negative result.

The bacterial isolate AG $4 \mathrm{M}$ showed a positive result for proteolytic activity having an average of $14.6 \mathrm{~mm}=2$ (moderate, $11-15 \mathrm{~mm}$ ). Lipase activity was also present with an average of $7.3 \mathrm{~mm}=1$ (low, $6-10 \mathrm{~mm}$ ). Amylase activity showed a negative result.

The bacterial isolate $A G 5 \mathrm{H}$ showed a positive result for proteolytic activity having an average of $19.6 \mathrm{~mm}=3$ (good, $16-20 \mathrm{~mm}$ ) (Figure 14). Lipase activity was also present with an average of $30 \mathrm{~mm}=5$ (very high, $>25 \mathrm{~mm}$ ). Amylase activity showed a negative result. 
The bacterial isolates' qualitative extracelluar enzyme activity was assessed based on the measurement of the halo zone (diameter in $\mathrm{mm}$ ) around the colony and scores were interpreted (Das 2014). The extracellular enzyme assays revealed that the bacterial isolates had proteolytic activity and lipase activity while having no amylolytic activity. Localization and activity of these enzymes reflect the feeding habits and intestinal morphology of the fish (Kuz'mina 2002), although extensive information on the activity distribution of various digestive enzymes along the intestines of different fish species is inconsistent (Kuz'mina 1979 \& Deguara et al 2003). All bacterial isolates showed moderate activity for protease coinciding on the statement of Izvekova (2007) stating that in considering the overall mass of mucosa, the cumulative proteolytic activities in the intestine were significantly greater than those in the pyloric caeca. Enzyme assay showed a low activity for lipase in isolates AG $1 \mathrm{~A}, \mathrm{AG} 3 \mathrm{M}$, and $\mathrm{AG} 4 \mathrm{M}$. On the other hand, isolate $\mathrm{AG} 5 \mathrm{H}$, revealed a very high activity of lipase, which raises the question as to why, because of the fact that black surgeonfish is herbivorous.

The differences in the biochemical, metabolic and enzymatic capacity may be due to the nature and compositions of the diet. This strongly affects the metabolic capabilities of fish (Rimmer 1987).

Overall, qualitative enzyme activity of the isolates showed that AGH5 is the most potent producer of enzyme having a score value of 8 (Table 7). This isolate is found in the hindgut region and studies have shown that bacteria found in this particular are have high enzyme activity because this is the site of fermentation in herbivorous fishes (Mountfort et al 2002).

Table 7. Qualitative extracellular enzyme activitiy (halo diameter) of some bacteria strains isolated from the gut segments of surgeonfish (Acanthurus gahhm)

\begin{tabular}{cccccc}
\hline \multirow{2}{*}{$\begin{array}{c}\text { Bacterial } \\
\text { Strains }\end{array}$} & $\begin{array}{c}\text { Isolated } \\
\text { from }\end{array}$ & \multicolumn{2}{c}{ Enzyme activity (scores) } & Total Score \\
\cline { 2 - 5 } & & Amylase & Lipase & Protease & \\
\hline AG 1A & Anterior gut & 0 & 1 & 2 & 3 \\
AG 2M & midgut & 0 & 0 & 2 & 2 \\
AG 3M & midgut & 0 & 2 & 0 & 2 \\
AG 4M & midgut & 0 & 1 & 2 & 3 \\
AG 5H & hindgut & 0 & 5 & 3 & 8 \\
\hline
\end{tabular}

Legend: 0 (0-5mm), 1 (low, 6-10mm), 2 (moderate, 11-15mm), 3 (good, 16-20mm), 4 (high, 21-25mm), and 5 (very high, $>25 \mathrm{~mm}$ )

Antibacterial activity was only observed in isolate $\mathrm{AG} 5 \mathrm{H}$, having a zone of inhibition of $20 \mathrm{~mm}$ (Fig. 4), against $S$. aureus but not in E. coli. In several studies on gut microbiota, it was shown that some isolates produces potent antibacterial substances that they secrete in order to successfully colonize and out compete other bacterial species. These antimicrobial peptides help maintain the gut microflora from accidental bacteria that may pass the gut of the fish. 


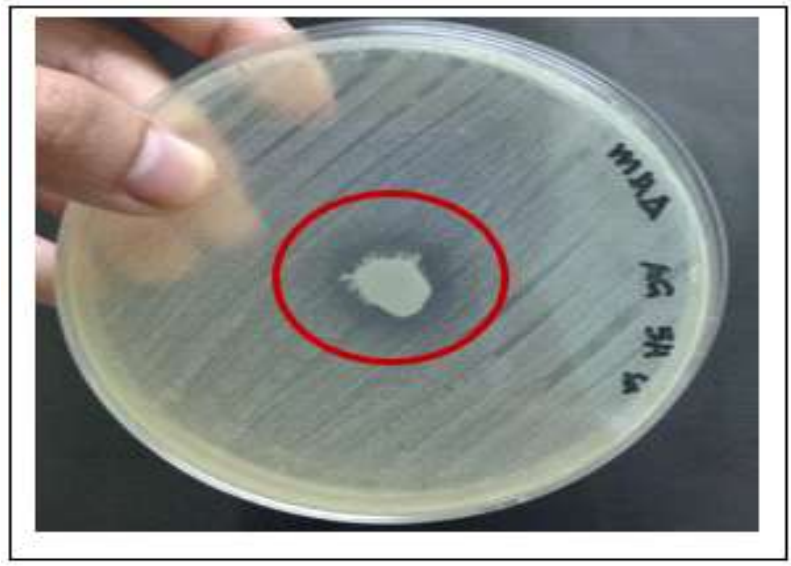

Figure 4. Isolate AG $5 \mathrm{H}$ showing a zone of inhibition against $S$. aureus

\section{CONCLUSION}

The cellulolytic, proteolytic and lipolytic enzyme activities of the isolates reflect the feeding habits and intestinal morphology of the fish. The diverse assemblage of enzymatic bacteria can be used in probiotics and to aid the development of feeds for the improvement of fish diets.

Isolate AG $5 \mathrm{H}$ was observed to have numerous metabolic capabilities namely having fermentative properties and reduction of sugars which can be used to reducing sugar (or glucose) from cellulose for the production of biofuels via microbial fermentation.

Isolate $\mathrm{AG} 5 \mathrm{H}$ had an antibacterial activity against $S$. aureus. This antibacterial activity might be a mechanism to outcompete other bacterial species and to maintain the microfloral diversity in the hindgut.

\section{RECOMMENDATIONS}

Further study should be done on the biological activties of the isolates. First, on the optimum activities of the extracellular enzymes under different levels of temperatures, salinity and $\mathrm{pH}$. Second, to positively identify the isolates based on molecular methods (ie 16S rRNA gene sequencing). Third, to determine quantitatively the activities of the extracellular enzymes. And lastly, to further determine the antimicrobial activties of the isolates, and using other qualitative and quantitative methods. 


\section{ACKNOWLEDGMENT}

The authors would like to thank the Research Services Division of the Iloilo Science and Technology University (ISAT-U) for the research fund. Acknowledgment is also given to the Science Laboratories of the Science Department of St. Paul University Iloilo and the Southeast Asian Fisheries Development Center-Aquaculture Department (SEAFDEC-AQD) for allowing the researchers to perform some parts of the experiments and other related activities using its facilities.

\section{LITERATURE CITED}

BAIRAGI A., GHOSH, K.S., SEN, S.K., RAY, A. K. 2002. Enzyme producing bacterial flora isolated from fish digestive tracts. Aquaculture International. 10: 109-121.

BANERJEE, G., MUKHERJEE, S., BHATTACHARYA, S., RAY, A. K. 2016. Purification and characterization of extracellular protease and amylse by the bacterial strain, Corynebacterium alkanolyticum ATH3 isolated from fish gut. Arab J Sci Eng. 41: 9-16.

BAYA, A. M., LUPIANI, B., BANDIN, I., HETRICK, F. M., FIGUERAS, A., CARNAHAN, A., MAY, E. M., TORANZO, A. E. 1992. Phenotypic and pathobiological properties of Corynebacterium aquaticum isolated from diseased striped bass. Dis. Aquat. Org. Vol.14:115-126.

BERGEY'S MANUAL OF SYSTEMATICS OF ARCHAEA AND BACTERIA. 2015. John Wiley \& Sons, Inc.

CHOAT J. H. 1991. The biology of herbivorous fishes on coral reefs. In: Sale PF (ed) The ecology of fishes on coral reefs. Academic Press, San Diego, pp 120-155

CLEMENTS, K. D. 1991. Endosymbiotic communities of two herbivorous labroid fishes Odax cyanomelas and Odax pullus. Mar. Biol. 106:223229.

CLEMENTS K.D., AND J. H. CHOAT. 1995. Fermentation in tropical marine herbivorous fishes. Physiol. Zool. 68:355-378.

COLWELL, R. R. AND LISTON, J. 1962. Bacterial flora of seven species of fishes collected at Rongelap and Eniwetok Atolls. Pacific Science. Vol. 16: 264-270.

DAS P., MANDAL, S., KHAN, A., MANNA, S. K., GHOSH, K. 2014. Distribution of extracellular enzyme-producing bacteria in the digestive tracts of 4 brackishwater fish species. Turkish Journal of Zoology 38: 79-88.

DEGUARA, S., JAUNCEY, K. AND AGIUS, C., 2003. Enzyme activities and pH variations in the digestive tract of gilthead sea bream. Journal of Fish Biology, 62, 1033-1043.

EDWARDS C.A., SUBLER S., (1998) Changes in biochemical properties of cow manure during processing by earthworms (Eisenia andrei, Bouché) and the effects on seedling growth. Envi. Sci 27:45-52 
FAO (Food and Agriculture Organization of the United Nations. 2008. Climate change for fishery and agriculture. Rome 3-5 June 2008.

GATESOUPE F, Cove`s D (2012) A spatiotemporal study of bacterial community profiles associated with Atlantic bluefin tuna larvae, Thunnus thynnus L., in three Mediterranean hatcheries. Aquac Res: $1-13$

GHOSH, K., S. K. SEN, AND A. K. RAY. 2002. Characterization of bacilli isolated from gut of rohu, Labeo rohita, fingerlings and its significance in digestion. Journal of Applied Aquaculture 12(3): 33-42.

IZVEKOVA, G., IZVEKOV, E., PLOTNIKOV, A. 2007. Symbiotic microflora in fishes of different ecological groups. Biology Bulletin 34(6): 610-618.

JACOB, M. B. AND M. J. GERSTEIN. 1960. Handbook of microbiology. Princeton, NJ: D. Van Norstrand Co. Inc.

KIM D. H., BRUNT J., AUSTIN B. 2007 Microbial diversity of intestinal contents and mucus in rainbow trout (Oncorhynchus mykiss). Journal of Applied Microbiology 102:1654-1664.

KUZ'MINA V.V., GOLOVANOVA I.L. AND KOVALENKO E. 2002. Separate and combined effects of cadmium, temperature and $\mathrm{pH}$ on digestive enzymes in three freshwater teleosts. Bulletin of Environmental Contamination and Toxicology 69 (2): 302-308.

MERRIFIELD, D. L., D. BURNARD, G. BRADLEY, S. J. DAVIES AND R. T. M. BAKER. 2009. Microbial community diversity associated with the intestinal mucosa of farmed rainbow trout (Oncoryhnchus mykiss Walbaum). Aquac. Res. 40:1064-1072.

MOUNTFORT D. O., CAMPBELL, J., CLEMENTS, D. K. 2002. Hindgut fermentation in three species of marine herbivorous fishes. Appl. Environ. Microbiol. Vol.68 No. 31374-1380.

NOORNISABEGUM, M. AND REVATHI, K. 2014. Analysis of gut bacterial flora from edible marine fishes of South east coast of India. Int. J.Curr.Microbiol.App.Sci. 3 (1): 523-528.

RANDALL. J. (1961a). A contribution to the biology of the convict surgeonfish of the Hawaiian Islands, Acanthurus tristegus sandvicensis. Pacif. Sci. 15: 215272

RANDALL, J. (1961b). Observations on the spawning of surgeonfishes (Acanthuridae) in the Society Islands. Copeia 1961: 237-238

RANDALL, J.E., 1987. Three nomenclatorial changes in Indo-Pacific surgeonfishes (Acanthurinae). Pac. Sci. 41(1-4):54-61.

RAY, A. K., ROY, T., MONDAL, S., AND RINGO, E. 2010. Identification of gutassociated amylase, cellulose and protease-producing bacetria in three species of Indian major carps. Aquaculture Research 41: 1462-1469.

RAY, A. K., GHOSH, K., RINGO, E. 2012. Enzyme-producing bacteria from fish gut: a review. Aquaculture Nutrition. 18; 465-492. doi: 10.1111/j.1365-2095.2012.00943.x 
REKHARI, Y. C., AGRAWAL, R., TRAKRO0, M. D., TIWARI, H. 2014. Qualitative and quantitative study on bacterial flora of farm raised common carp, Cyprinus carpio in India. Afr. J. Microbiol. Res. Vol 8 (11): 1125-1129.

RIMMER D. W., WIEBE, W. J. 1987. Fermentative microbial digestion in herbivorous fishes. Journal of Fish Biology. Vol. 31, Issue 2 229-236.

RINGO E. AND GATESOUPEB, F. J. 1998. Lactic acid bacteria in fish: a review. Aquaculture. 160: 177-230. doi.org/10.1016/S00448486(97)00299-8

RINGO, E. 2008. The ability of carnobacteria isolated from fish intestine to inhibit growth of fish pathogenic bacteria: a screening study. Aquaculture Research. 39, 171-180. doi: 10.1111/j.13652109.2007.01876.x

SAHA S., ROY, R. N., SEN, S. K., RAY, A. K. 2006. Characterization of celluloseproducing bacteria from the digestive tract of tilapia, Oreochromis mossambica (Peters) and grass carp, Ctenopharyngodon idella (Valenciennes). Aquac Res 37, 380-388.

SANGILIYANDI, G. AND P. GUNASEKERAN. 1996. Extracellular lipase producing Bacillus licheniformis from an oil mill refinery effluent. Indian Journal of Microbiology 36: 109-110.

YAGHOBI, M., HEYRATI, F. P., AGHI, M. A., DORAFSHAN, S., MAHMOUDI, N. 2014. Intestinal microbiota of striped catfish, Pangasionodon hypophthalamus (Sauvage, 1878) fed on dietary nucleotide. Iran J. Ichthyol. 1 (4): 274-280. 